\title{
Ricoeur in South Africa. Some remarks on his impact beyond philosophy
}

\author{
Bernard Lategan \\ Stellenbosch University, South Africa \\ bcl@sun.ac.za
}

\begin{abstract}
The work of Paul Ricoeur is of much wider significance than just for the field of philosophy. This contribution discusses the impact of his ideas on developments in South Africa in three areas beyond philosophy: discourse analysis, concepts of selfhood, and the role of memory in social transformation. His dynamic understanding of communication helped to liberate discourse analysis in South Africa from an a-historical approach by focusing on the role of the reader, the context of reception and the transformative power of the text. His innovative work on the relationship between the self and the other has the potential to lead to a more inclusive understanding of being human together and to an enriched and expanded concept of identity. His extensive work on memory, history and forgetting can provide the basis to unlock the future potential of memory and for a memory liberated from being defined and held ransom by the past.
\end{abstract}

Key words

Ricoeur, South Africa, discourse analysis, the transformative power of texts, selfhood, identity, history, the future potential of memory

\section{Introduction}

The impact of Paul Ricoeur's work reaches far beyond national borders or the limits of philosophy itself. His reception in philosophical circles in this part of the world is evident from other contributions to this volume. Being neither a philosopher nor an expert on Ricoeur, my aim is to focus on his influence beyond philosophy. The intention is not to provide a comprehensive overview - historically or otherwise - but to discuss his significance in the context of the major social transformation which the 
country experienced recently. As will become evident, in some areas his impact changed the course of events, in others it remains a potential influence not yet fully realized.

Tracing Paul Ricoeur's impact in this way takes place against a specific existential backdrop. In the spirit of the theme of the conference ("From where do you speak?"), the context of the present analysis is that of a society grappling to rediscover, reimagine and rebuild a lost or at least a badly damaged humanity in the wake of a traumatic past, in a setting of continuing and even increasing inequality, battling with unresolved memories of injustice and violence. We find ourselves in the aftermath of a remarkable political and social transformation, guided by visionary leadership and with the promise of a more humane society. This dream came under severe strain during the last decade but is now showing signs of recovery. Personally, I speak as member of an older cohort who in many ways do not fully understand the aspirations and dreams of a new, often impatient and angry generation. And I speak as some-one who has structurally and personally benefitted from a previously unjust dispensation and who remains a beneficiary, regardless of how my views may have changed in the meantime.

Such existential concerns are not foreign to Ricoeur's own approach. His perceptive and moving analysis of the Truth and Reconciliation Commission's work in both its successes and failures (Memory, History, Forgetting, 483-486) echoes this existential concern - although of course he was writing about an earlier phase of the process.

It is impossible to do justice to the rich and multifaceted contribution of Ricoeur, dealing with all its wide-ranging perspectives and its many original (and often provocative) insights. I shall therefore concentrate on three "spheres of influence" beyond philosophy: discourse analysis (focusing on his Interpretation Theory); selfhood (in conversation with The Oneself as Another) and memory (referring mainly to Memory, History, Forgetting) ${ }^{1}$. As will (hopefully) become clear in due course, all three are presented under the banner of "liberation".

1 Subsequently quoted as $I T, O A$ and $M H F$. 


\section{Discourse analysis}

The impact of Ricoeur on discourse analysis in South Africa, especially in the field of biblical exegesis, has been extensive. By the time his Interpretation Theory appeared in 1976, discourse analysis was the dominant method used by local interpreters of biblical material. There were historic reasons for this - in part the legacy of events during the twenties and thirties of the previous century which has had a lasting effect on the theory and practice of exegesis. I refer of course to the (in)famous Du Plessis saga ${ }^{2}$. Leaving the sensational details of the story aside, the heart of the matter had to do with the status of biblical texts, whether they contain timeless truths and therefore are "infallible", but more importantly for our purpose, whether they are subject to historical change. Fundamentalism in theological circles has of course a long history and is certainly not restricted to South Africa. But here it became the willing partner in a political project which in the end produced an all-encompassing and all-pervasive ideology of "separate development", based on the principle of racial segregation. The process was perhaps not initiated by theology, but certain theologians and influential parts of the church not only provided moral support and theological justification but also important conceptual ideas as part of the over-all enterprise.

The crucial factor in this regard was an a-historical view of the text and of social reality, resulting in a mind-set of closure and isolation. "Higher criticism" was the biggest threat to the idea of the infallibility of the bible and the "eternal truths" it contains. But how can one suppress the undeniable historical character of these texts? In this regard, the option offered by structuralist linguistics of a synchronic (as opposed to a diachronic) approach to the text provided a welcome escape route. More than thirty years after the Du Plessis case, under the influence of Eugene Nida and Jannie Louw, discourse analysis flourished in South Africa, but of a very specific kind. The leading concept was "text-immanent" exegesis, meaning that only the internal relations of the components of the text were taken to consideration, to the exclusion any historical issues of origin or pragmatic matters of application. The closure of the text also meant its isolation.

2 See Nash 1997, Lategan 2004. 
What was happening in the specialized field of exegesis had wider ramifications. The urge for closure and isolation affected not only theology, but also political and ideological thinking. The obsession with Grense (the title of a controversial book by the theologian-turned-politician Andries Treurnicht) was based on an understanding of borders as absolute barriers and not as porous demarcations. One of the notorious exegetical examples of the time was the interpretation of Acts $17: 26^{3}$ as part of the justification for apartheid. The statement that God had for all nations "marked out their appointed times in history and the boundaries of their lands" was understood as a validation of the policy of segregation. Boundaries (whether these were markers of geographical, cultural of racial divisions) were absolute, timeless and permanent - and in terms of the wider theology of the "orders of creation" (skeppingsordeninge) sacrosanct and immutable. Closure in this way ipso facto meant the exclusion of others.

What has all this to do with Ricoeur?

In some respects, Ricoeur was far removed from the internal ideological debates of the apartheid era and from the conservative biblical hermeneutics which developed in the wake of the Du Plessis case. In other respects there was an uncanny close link with the latter (even if Ricoeur himself was unaware of it). This link was not only the common emphasis on "discourse" ("discourse analysis" in the case of South African biblical hermeneutics and "discourse and the surplus of meaning" in the case of Ricoeur) but more importantly, his close familiarity with French structuralism and especially Saussurian linguistics which provided the basis for the "textimmanent" exegesis practiced in South Africa. Ricoeur was fully aware of the underlying presuppositions of this linguistic approach and of the wider philosophical framework in which it was embedded. The important difference was that the conclusions he drew were in direct opposition to the way South African discourse analysis appropriated the same tradition. It is therefore necessary to say something more about the strategy which Ricoeur employed to arrive at his position.

3 "From one man he made all the nations, that they should inhabit the whole earth; and he marked out their appointed times in history and the boundaries of their lands" (New International Version). 
In his IT Ricoeur introduces three sets of binary relationships: "event and meaning", "sense and reference", and "explanation and understanding". The dialectic tension between the members of each set is characteristic of most forms of communication and provides the dynamics which drives the process. Each component represents either a dynamic or a static moment which constantly alternates with the other. The (dynamic) event of experience or insight enables its retention in the form of a (static) message (written or otherwise); this (static) sense of the message inevitably points to its (dynamic) reference; the (static) explanation of this reference creates the conditions for (dynamic) understanding. This provides the rationale for Ricoeur's focus on semantics rather than on semiotics - a distinction which for him was the key to the whole problem of language (IT 8).

Leaving technical details aside, what Ricoeur offers here is a fundamental critique of any a-historical approach to understanding and of any attempt to enclose the text within his own borders. As he explains in $M H F(194,247$, 253), this move was motivated by his own discomfort with the limitations of structuralism and its "disjunction between the internal structure of a text and any extratextual reality" (247).

The impact on biblical hermeneutics in South Africa was far-reaching. Not only did it put paid to the fundamentalist attempt to enclose the text within itself to safeguard it from the attacks of higher criticism and to render it immune to the ravages of time and the inevitability of historical change, but more importantly, it set the text free to unfurl to its full extent and to explore every perspective within its orbit.

This liberation was not restricted to the narrow terrain of linguistic construction or to the level of literary theory. It had a much wider significance - it opened the door for reception, the recognition of the importance of social location, and inadvertently contributed to the rise of contextual theology.

These developments cannot of course be solely ascribed to the influence of Ricoeur. Other important influences also played their part like reception theory, audience criticism, the rise of contextuality, the critique of foundationalism, and forms of liberation theology. Although Ricoeur was familiar with most of these, and although he worked in tandem with many of them (cf. his awareness of the role of the hearer, his use of speech act 
theory and the like) he pioneered his own unique approach. His greatest contribution was to provide an overall framework to draw these diverse elements and forces together and to develop a more comprehensive way to account for the relations between them. This had profound consequences, some not so obvious at the time. I shall highlight only three of these which were of special significance in the South African context:

\section{A fundamental shift in power relations}

Breaking out of the text as an assumed closed structure by letting reference follow its course led eventually to an important shift in power relations. Traditionally the "author" or the "text" were in control of determining the meaning of the text. Recognizing the reader and especially the creative role of the reader in producing (or co-producing) meaning undermined this assumed dominance. In fact, it provided a real Archimedean point from where the status quo could be challenged, making it possible to critique embedded residues of dominance, be they of cultural, ecclesial, colonial, gender or whatever nature. The result was an extensive liberation and "democratization" of the reading process, opening it up to a whole new range of readers. Reading from the perspective of the oppressed, the marginalized and the formerly excluded became an important strategy for all kinds of liberation theologies and identity politics. In some cases the pendulum swung to the other extreme, where identity politics led to new forms of exclusion. In order to safeguard the privileges claimed for the group, its borders became narrower and narrower and those who qualified fewer and fewer.

\section{Broadening - and balancing - the scope of interaction}

Secondly, Ricoeur's comprehensive approach expanded the scope of communicative interaction. The emphasis on the "social location" of the reader/hearer, awareness of the position "from where I speak" and the productive role of the allowed contemporary and unconventional readers to join in the conversation. But this development could also lead to a certain imbalance in the reading process - which in some cases resulted in the reader becoming the main or sole arbiter of the "meaning" of the text.

In this regard Ricoeur had a sobering influence with this insistence on both the "right of the reader and the right of the text" which "converge in an 
important struggle that generates the whole dynamic of interpretation" (IT 32). Without going into the details of the intriguing exchanges between the implied and real reader and the implied and real author (cf. Lategan 2009:466-468), it suffices to say that by incorporating both the static and dynamic aspects of the text in a comprehensive understanding of the text, Ricoeur restored a much-needed balance between the various drivers of the process.

\section{The transformative power of proposed worlds}

One of the most consequential insights of Ricoeur is the transformative nature of discourse itself. He writes: "The inscription of discourse is the transcription of the world, and transcription is not reduplication, but metamorphosis" (IT 42). This becomes a basic premise not only of his historiography, but also underpins the very act of writing which by definition cannot be a reduplication of reality. A whole network of interrelated considerations thus came into play, which leads to his well-known concept of the re-description of reality, offering "a proposed world which I could inhabit” (2016:72). This holds both for non-fictional and fictional texts who each presents this alternative world by different means. Once the contours of such a world is recognized, it becomes a desired outcome and acts as a powerful means of transformation.

Local examples of such proposed worlds which are couched in visionary, prophetic, theological or legal language are the Freedom Charter (1955) with its repetitive use of the prophetic "shall" to outline the contours of a non-racial South Africa; the Belhar Confession (1986) with its rejection of the idea of the irreconcilability of people and its vision of a just society; The Option for Inclusive Democracy (1987) with its emphasis on human dignity, equality, unity, freedom, rights and responsibility; and the South African Constitution (1996) with its vision of an inclusive democracy based on a set of fundamental human rights.

As far as discourse analysis is concerned, Ricoeur has had a real and lasting effect on developments in South Africa. He helped to liberate the text from its static and restricted existence to open vistas not only "in" or "behind", but especially "in front of" the text. In contrast, in the areas of selfhood and memory, his impact is at this stage more of a potential nature. 


\section{Selfhood}

The second area of influence concerns the kind of society South Africans are trying to establish in the wake of apartheid. To link this to what has been said above about "proposed worlds", let us take the preamble to the Constitution of 1996 as our point of departure:

We, the people of South Africa ... adopt this Constitution ... so as to heal the divisions of the past and establish a society based on democratic values, social justice and fundamental human rights; lay the foundations for a democratic and open society in which government is based on the will of the people and every citizen is equally protected by law; improve the quality of life of all citizens and free the potential of each person ...

At the root of the divisions to be healed lies the vexed issue of identity - more precisely, concepts of selfhood and their specific use in the South African context. Without getting drawn into the details of this over-researched, over-discussed and still unresolved topic ${ }^{4}$, it is important to remember that the very origin of selfhood is premised on the awareness of difference the realization that I am not like others, that I am my own person. This is the essential prerequisite for any sense of personal identity. But this "primordial" realization of being different can be extended in one of two directions - towards detachment and alienation or towards convergence and solidarity.

Especially in societies with high levels of diversity like South Africa (and Africa for that matter), difference almost by default attracts negative associations. What is unfamiliar and strange quickly becomes a threat, and the other appears as a potential enemy. The usual strategies to deal with this discomfort are separation, distanciation, and isolation - the same forces we encountered in our discussion of discourse analysis and the attempted imprisonment of the text. In the case of identity this manifests itself as a process of contraction and isolation, retreating behind the (assumed safe) bulwark of a "mono"-identity. Difference thus becomes the means to

4 See for example Erikson 1966, 1980, Marcia 1966, Waterman 1984, Berzonsky 1990, Cass 1996, Castells 1997, Grotevant 1997, Malouf 2000, Stets \& Burke 2000, Sen 2006, Van Huyssteen 2006, Roefs 2006, Goosens 2008, Steinberg 2008, Clingman 2009. 
divide and rule, resulting in the well-known system of classification (and discrimination) on the basis of culture, class and race.

Reversing this trend is easier said than done. Many "solutions" are either too shallow or too idealistic to be effective. The "melting-pot" idea seldom takes the tenacity of remaining "own" identities fully into account. The plea for "tolerance" is too weak to overcome the power which keep differences intact.

In this regard Ricoeur opens other perspectives. His essays on reconnaissance and especially his Oneself as Another, provide a rich resource to rethink our concepts of selfhood and the dynamics of identity formation. His intriguing proposal in Oneself as Another invites further exploration ${ }^{5}$ :

Oneself as another suggests from the outset that the selfhood of oneself implies otherness to such an intimate degree that one cannot be thought of without the other, that instead one passes into the other, as we might say in Hegelian terms. To 'as' I should like to attach a strong meaning, not only that of a comparison (oneself similar to another) but indeed that of an implication (oneself inasmuch as being other) (OA 3).

What this "being other" exactly entails remains unclear - an issue to which we shall return shortly. It is impossible to do full justice here to Ricoeur's many-faceted explorations of "a hermeneutics of the self" (OA 1). I shall restrict my remarks to three aspects which are of specific relevance for our theme.

The first aspect relates to the inherent reflective nature of the self. Instead of "the immediate positing of the subject" as an "I", the "self" already presupposes a reflective detour $(O A$ 1). Personal identity is therefore not a fixed entity, but a temporal dimension of human existence ( $O A 114)$ and the result of a dynamic process of being constituted.

The second is the role of the other in the formation of the self. Far from being an outsider, the other is intimately involved in the realization of the

5 It is important to keep in mind that this is not the first formulation of selfhood in terms of the other - human solidarity has a long history on the African continent, expressed by a variety of images and expressions of which "I am a human being through other human beings" is one of the best known. 
self. This depends on the "dialectic of self and the other than self" (OA 3). The "need and lack" of the self, that "what one is incapable of procuring by oneself" (with reference to Aristotle - OA 185) requires the "mediation of the other" (with reference to Charles Taylor - OA 181). What is needed is "the internalization of the voice of the Other in the Same" (OA 339).

The third is the recognition of the complex or multiple nature of identity itself - or what Ricoeur calls the "plurality in the very constitution of the self" (OA 296). Attempts to reduce identity to a single denominator by eliminating all that the self is not, are doomed to fail. This means that selfhood is not only open to change, but also to expansion and enrichment.

The self is therefore "work in progress". It is a living thing and therefore open to re-imagination, expansion and adjustment. While the sense of being the same person remains intact, the self is continuously changing. Ricoeur thus provides an important Vorlage and an ideal starting point for our purpose, namely (as he himself formulates it) "the formation of a concept of selfhood defined by its openness and its capacity to discover" (OA 339).

But can these ideas be taken further and tested in more demanding circumstances? Much of what Ricoeur writes about reciprocal relations between the self and the other still remains within the amicable sphere of “friendship' (OA 180-194). Would it still hold in a hostile environment marked by suspicion and alienation? In other words, what does this mean in the context like South Africa where - despite good intentions and strenuous efforts - the dominating paradigm (physically and psychologically) is still one of distance and separation? As we have seen, the experience of the self and the other (both from the perspective of the colonized and of the colonizer) has from the start been framed in terms of difference, steeped in adversarial imagery and driven by the experience of strangeness and the consciousness of distance. Despite traditions of mutual interdependence and of human solidarity that were available at the time, despite historical examples which proved the opposite, the dominant experience and consciousness was that of contrast and dissimilarity. This was reinforced by ideological driven policies and practices of separation, classification and denigration. An already fragile humanity was structurally and forcefully segmented even deeper. The distance between the self and the 
other appeared to be unbridgeable both conceptually and in terms of social relations. The basic premise of this mind-set - as subsequently formulated in the Belhar Confession - is the irreconcilability (onversoenbaarheid) of people. The pervasiveness of this mentality is evident in its continuing reappearance in different guises - the latest example being the sporadic flaring of xenophobic violence in South Africa.

Is a different approach thinkable? What if we see strangeness as a resource and the other as catalyst to restore our own humanity? The case for the (counter-intuitive) embracing of strangeness and of the other has been argued more extensively elsewhere (Lategan 2018) - here only a bare outline can be presented.

First of all, a preliminary but crucial step needs to be taken. Before the gap to the other can be bridged, before we can show solicitude (SO 189-190) or apply the golden rule (OA 320) as Ricoeur urges us to do, the ground for this to happen must first be prepared by establishing a broader base in the self. As Ricoeur himself points out, intersubjectivity starts within the self by the "derivation of a unique kind of alter ego starting from the ego" (OA 323). This "internal" subjectivity provides the basis for an "external" intersubjectivity. It is not what the self does to others, but what happens to the self that should be the starting point.

Secondly, a reversal of a different kind is required: from a negative to a positive appreciation of strangeness and the other. Our "natural" instinct is to treat the unfamiliar and the other with caution and suspicion - what is strange is not only experienced as uncomfortable, but often as threatening and dangerous. In an attempt to deal with this situation, a whole range of strategies is employed - with manifestations in history, culture, religion, art and many other fields - to "domesticate" the stranger. This can be done by more peaceful or by more aggressive means, ranging from neutralization, "cleansing", annexation, assimilation, conversion, "re-education", subjection, enslavement, and even elimination. In all these instances, the self remains the standard to which the other is compared and by which the stranger is judged. 
But what if the unfamiliar becomes the stimulus to explore alternative viewpoints, to complete our own incompleteness ${ }^{6}$, expose ourselves to worlds far beyond our own limited experience? What if the other is not only seen as an opponent or stranger to be avoided or resisted, but as a rich resource and as the key to a fuller understanding of what it means and can mean to be human? This opens the possibility of an extension and enrichment of the self which can serve as a more secure bridgehead to build those bridges we talk so much about, daring us to cross the divide - the very step we are hesitant to take despite our pious declarations that "we really should get together".

With this expansion and enrichment also comes a liberation of a special kind - a liberation consisting in the first place of a critical awareness of and a conscious effort to distance oneself from oneself and from embedded stereotypes and prejudice. As Simmel points out, because the stranger as outsider is at a distance, he or she offers a certain "objectivity" that frees us from our preconceived ideas ${ }^{7}$. But the concept has wider implications. It also implies freeing oneself from the confines of a narrow set of defence mechanisms which usually structure relations with the other - mechanisms of justification, demarcation, exclusion and entitlement. There is a much wider spectrum of modalities available for shaping the interaction with the other, like engagement, inclusion, respect, esteem and reconciliation. All of these have the potential to provide stronger foundations for the so much desired more humane society.

\section{Memory}

The third area of influence concerns memory, the main theme of Ricoeur's magnus opus Memory, History and Forgetting. Here he integrates many of the wide-ranging ideas which occupied him all through his life ${ }^{8}$. Again, it will be impossible to traverse this vast landscape in any detail. I shall

6 Cf. Nyamnjoh 2015.

7 " ... he (the stranger) is freer practically and theoretically; he surveys conditions with less prejudice; his criteria for them are more general and more objective ideals; he is not tied down in his action by habit, piety, and precedent" (Simmel 1950[1908]:403).

8 The present attempt to open a future for memory has as background the incredibly rich and dense discussion of $M H F$ and its long and intense exploration of the enduring dialectic between memory and history (see Part 3 of the book, especially 393). A brief 
concentrate on one concern which has important existential implications in the context of South Africa, namely the directional orientation of memory. The lodestar of Ricoeur's exploration is Aristotle's dictum: "All memory is of the past" (MHF 6). This fixation on the past is not without problems, for Ricoeur at the same time admits that memory as such only functions in the present. He writes: “...the return of a memory can only take place in the mode of becoming-an-image" (MHF 7). These images are operational in the present, not in the past. It is this tension between the orientation (that is, towards the past) and the mode of memory (as a phenomenon in the present) which we shall take as our cue for this final section.

While it is no doubt true that the object, or shall we rather say the subject matter of memory is the past, it is equally clear that the same mediating, detouring, and interpretive process which we encountered in our discussion of discourse and of selfhood is at work here. Because of the pastness of the past we do not have direct access to it, but only via a reconstruction of that past. Even in its "scientific" version as history, where the obligation is to verify the validity of its truth claims, such (oral or written) history already represents a "re-telling", and thus a reconstruction in itself9.

Just as it is impossible to restrict the reference of discourse to the limits of the text, it is likewise impossible to confine memory to the prison of the past. This is what Ricoeur senses when he makes the distinction between Vergangenheit (the irrevocable lost past) and Gewesenheit (the past that is still present - MHF 362).

The term "present" refers of course to a relative point in time. What at a certain stage is still "future", inevitably becomes "present" and is just as surely doomed to become "past" as time moves on ${ }^{10}$. These are positions on one and the same timeline, a line that is - most importantly for our

analysis cannot deal with all the complex and intertwined themes and sub-themes which Ricoeur explores here so patiently and masterfully.

9 To repeat Ricoeur's own statement which we quoted in the first section: "The inscription of discourse is the transcription of the world, and transcription is not reduplication, but metamorphosis" - IT 42).

10 Cf. MHF 433-4: "An important corollary to the thesis of the survival of images of the past in a state of latency is, in fact, that any given present is, from the moment of its appearance, its own past. For how could it become past if it were not constituted at the same time as it was present?" 
argument - bi-directional, in the sense that it is open to perspectives in both directions.

What would happen if we start to explore the future potential of memory? This may not be so nonsensical as it sounds. The persistence of memory (in whatever form - as recollection, re-presentation, or re-imagination) is the consequence of a certain "excess of memory" which propels it forward. Ricoeur himself offers some hints in this regard. In an intriguing passage, he commends Todorov's advice to extract "the exemplary value" from traumatic experiences and then adds: "If the trauma refers to the past, the exemplary value is directed to the future" (MHF 86). How this re-direction should be achieved in practice, remains unclear.

We therefore need a "conceptual readjustment" - to use a formulation of Ricoeur in a different context (OA 311). My proposal is to reverse the direction of orientation and follow the trajectory of memory not towards the past but along its thrust towards the future. The inherent logic of memory propels it in this direction. Between the closed and already determined realities which constitute the past, memory is a phenomenon of the present which has the potential to mediate the possibilities still open for the future.

The plea is not to forget the past. In this regard, Ricoeur's views on forgetting are problematic. In essence, forgetting acquires for him negative associations - it is a lack, a danger to be avoided. But then again it is a necessary condition for forgiveness ( $M H F$ 412). This tension give rise to all kinds of confusion (MHF 412, 414, 479).

Lapses of memory no doubt cause their own difficulties, but of far greater importance is the constitutive role of forgetting in the very formation of memory. Memory is what remains after we have forgotten. It comes onto being by virtue of forgetting, or to put it differently, memory depends on forgetting. Memory gets its distinctive profile by chipping away those bits we do not remember.

Forgetting as such is therefore not the problem, at least not as far as enduring memories are concerned - that is, memories we cannot forget. The intensity of destructive memories and traumatic experiences makes it unrealistic - and disrespectful - to expect victims to forget and "just move on". The ineradicable nature of these memories and the finality of unchangeable past events rule out forgetting as an option. 
But is the mantra of the future potential of memory anything more than just another catchy slogan? What does it mean in concrete terms? I would suggest that it comprises of a comprehensive re-orientation which affects the process of remembering on different levels.

On the most basic level it entails a reversal of perspective, shifting the focus of memory from its fixation on the past to its implications for the future as we have explained above.

On a second level, it means expanding the modes of remembering to include more than the customary justification of anger and pain, the historical grounding of past injustices or the validation of claims for restoration. The challenge is to think creatively how a specific memory can actually shape the future, thereby ensuring that it becomes part of that future. This is a more enduring way in which injustices of the past can influence future developments.

On a third level, it means going beyond a preventative understanding of memory, that is, an understanding that has as its main goal to prevent bad things from happening again. The famous statement of Nelson Mandela will forever ring true: "Never, never and never again shall it be that this beautiful land will again experience the oppression of one by another". But this is only half the story. We cannot contend ourselves only with what should not happen. Of equal (and perhaps even greater) importance is what should happen.

Ricoeur provides us with a chilling reminder in this regard (MHF 328). Because the Soviet Gulag system of prison camps was only remembered as a past event and did not receive any "positive" future, because an alternative approach was neither imagined, articulated nor propagated, it became a model which could be repeated again - in even more grotesque form - at Auschwitz and the like.

On a fourth level, it means accepting the dynamic, changing nature of memory, the fact that our memories are evolving, that they are open to criticism and correction, that they can be adjusted and recalibrated, without denying or betraying what did happen.

This even applies to trauma, of which I am hesitant to speak because it is such a personal matter. But if trauma can be more than merely re-living 
a horrific event, and become a re-imagined way to affect the future, it might assist in breaking out of the downward spiral of despondency and hopelessness.

To be more specific:

- What would be an alternative future for the hatred of Afrikaners towards the British for the deaths of thousands in the concentration camps and the devastation of farms as part of a scorched earth policy?

- What alternative to revenge and retaliation against those responsible for the horror of the Sharpeville massacre?

- What alternative to the indiscriminate killings at Marikana, despite a "new" South Africa and a Constitution with an internationally applauded Bill of Human Rights?

- What alternative to the emotive question of land redistribution fuelled on the one hand by deeply inscribed memories of humiliation and injustice and the damage caused by large-scale dispossession and forced removals and on the other hand by memories of a "century of injustice", the painful reclaiming of land and property and then handed down over generations?

If no future dimension can be discovered in these painful memories they will continue to block creative solutions which are there for the taking and which can open real possibilities of "a better life for all".

Even in extreme cases where the memory is so abhorrent that any reference to its possible "future" seems a mockery, such a memory still has the possibility to transcend its past on the strength of the inexorable logic which drives it forward. A case in point is the series of conversations Pumla Gobodo-Madikizela had with the condemned Vlakplaas murderer Eugene de Kock, known as "Prime Evil". What prompted Gobodo-Madikezela to make contact with de Kock in the first place was not merely curiosity to get "inside the head" of such a ruthless operator, but the unexpected response of two of the widows of his victims when they met him face to face. They sensed that something more was happening - a "surplus" they could not explain but which prompted one of them, Mrs. Faku, to say afterwards: "I would like to hold his hand, and show him that there is a future, and that he still can change". They sensed that something more was happening - a "surplus" they could not explain. Gobodo-Madikizela (2003: 15) comments: 
“The image of the widow reaching out to her husband's murderer struck me as an extraordinary expression - an act - of empathy, to shed tears not only for her loss but also, it seemed, for the loss of de Kock's moral humanity."

What makes the difference even in such extreme cases is the "more" of memory which opens unexpected possibilities. Let me be clear that the future envisioned here is not the "anticipation of possibility" implied by Heidegger's "Sein-zum-Tode" with its narrow and negative focus (Heidegger 1962: 242, MHF 356). The "excess of memory" surpassing the past which is at stake here is not driven by Angst for death, but by life in all its fullness and joy.

\section{Conclusion}

Hopefully these few remarks, often merely touching the surface of things will suffice to demonstrate that Ricoeur's influence stretches far beyond philosophy and that it is of special significance to South Africa. As we have seen, in some areas his work has already changed the course of events - in other cases it is still a potential impact. In all three areas, we encountered recurring themes - the mediated and therefore dynamic nature of discourse, of selfhood and of memory, the resistance to closure and restriction, the power of dialectic opposites, the promise of a futureoriented perspective, and the priority of the possible above what is real. But above all the liberating thrust of his thought, leading to freedom of a special kind - freedom from the confines of an enclosed text, from a monoand an impoverished self and from a memory defined and held ransom by the past.

\section{Bibliography}

Belhar Confession 1986. Dutch Reformed Mission Church in South Africa.

Berzonsky, M 1990. Self Construction across the Life-Span: A Process View of Identity Development. In Greg J Neimeyer and Robert E Neimeyer (eds.). Advances in Personal Construct Psychology, Vol. 1. Greenwich, CT: JAI Press, 155-186. 
Cass, V 1996. Sexual Orientation Identity Formation: A Western Phenomenon. In RP Cabaj and TS Stein (eds.). Text-book of Homosexuality and Mental Health. Washington, DC: American Psychiatric Press, 227-251.

Castells, M 1997. The Power of Identity. Oxford: Blackwell Publishers.

Clingman, S 2009. The Grammar of Identity. Transnational Fiction and the Nature of the Boundary. Oxford: Oxford University Press.

Constitution of the Republic of South Africa no 108 of 1996. Cape Town: Republic of South Africa.

Erikson, E 1966. Childhood and Society. New York: W. W. Norton.

Erikson, E 1980. Identity and the Life Cycle. New York: W.W. Norton. Freedom Charter 1955. Kliptown: Congress of the People.

Gobodo-Madikizela, P 2003. A Human Being Died That Night. A Story of Forgiveness. Cape Town: David Philip.

Goossens, L 2001. Global Versus Domain-Specific Statuses in Identity Research: A Comparison of Two Self-Report Measures. Journal of Adolescence. 24:681-699.

Grotevant, H 1997. Coming to Terms with Adoption: The Construction of Identity from Adolescence into Adulthood. Adoption Quarterly. $1: 3-27$.

Heidegger, M 1962. Being and Time. Translated by J Macquarrie and E Robinson. New York: Harper \& Row.

Lategan, B, Kinghorn, J, Du Plessis L and De Villiers, E 1987. The Option for Inclusive Democracy. A theological-ethical study of appropriate social values for South Africa. Stellenbosch: Centre for Contextual Hermeneutics. 
Lategan, B 2004. Preparing and keeping the mindset intact. Reasons and forms of a theology of the status quo. In W Weisse and C Anthonissen (eds.). Maintaining apartheid or promoting change? The role of the Dutch Reformed Church in a phase of increasing conflict in South Africa (Religion and Society in Transition Vol. 5). Münster: Waxmann.

Lategan, B 2018. In Praise of Strangeness. Exploring the hermeneutical potential of an unlikely source. SJT. 4(1):267-296.

Malouf, A 2000. On Identity. Londen: Harvill Press.

Marcia, J 1966. Development and validation of ego identity status. Journal of Personality and Social Psychology. 3:551-8.

Nash, A 1997. How Kierkegaard came to Stellenbosch: the transformation of the Stellenbosch philosophical tradition. SA Journal of Philosophy. 16:129-139.

Nyamnjoh, F 2015. Incompleteness: Frontier Africans and the currency of conviviality. Journal of Asian and African Studies. 1-18.

Ricoeur, P 1976. Interpretation Theory: Discourse and the surplus of meaning. Texas Christian University Press.

Ricoeur, P 1992. Oneself as Another. Chicago: University of Chicago Press.

Ricoeur, Paul 2004. Memory, History, Forgetting. Chicago: Chicago University Press.

Ricoeur, P 2016 [1981]. Hermeneutics and the Human Sciences. Cambridge Philosophy Classics. Cambridge: Cambridge University Press.

Roefs, M 2006. Identity and race relations. In: Pillay, Udesh, Benjamin Roberts and Stephen Rule (eds.). South African Social Attitudes. Changing Times, Diverse Voices. Pretoria: HSRC. 77-97.

Sen, A 2006. Identity and Violence. The Illusion of Destiny. New York: WW Norton.

Simmel, G 1950. The Stranger. In Wolff, Kurt H. 402-408. The Sociology of Georg Simmel. 
Steinberg, L 2008. A Social Neuroscience Perspective on Adolescent RiskTaking. Developmental Review : DR. 28(1):78-106. [Online]. Available: http://doi.org/10.1016/j.dr.2007.08.002. [Accessed 18 September 2018].

Stets, J and Burke P 2000. Identity Theory and Social Identity Theory. Social Psychology Quarterly. 63:224-37.

Van Huyssteen, JW 2006. Alone in the World? Human Uniqueness in Science and Theology. The Gifford Lectures, Grand Rapids: Eerdmans.

Waterman, A 1984. Identity Formation: Discovery or Creation? Journal of Early Adolescence. 4:329-341. 